\title{
Geo-Historical and Geomorphological Evolution of the Sabkhas and Ridges at the Al-Khiran Area, State of Kuwait
}

\author{
Adeeba E. Al-Hurban ${ }^{1}$, Hamdy I. El-Gamily ${ }^{2,3}$ \\ ${ }^{1}$ Department of Earth \& Environmental Sciences, Faculty of Science, Kuwait University, Kuwait City, Kuwait \\ ${ }^{2}$ Geoinformatics Center, Kuwait Institute for Scientific Research (KISR), Kuwait City, Kuwait \\ ${ }^{3}$ National Authority for Remote Sensing and Space Sciences (NARSS), Cairo, Egypt \\ Email: gamily@gmail.com
}

Received March 25, 2013; revised April 29, 2013; accepted May 29, 2013

Copyright (C) 2013 Adeeba E. Al-Hurban, Hamdy I. El-Gamily. This is an open access article distributed under the Creative Commons Attribution License, which permits unrestricted use, distribution, and reproduction in any medium, provided the original work is properly cited.

\begin{abstract}
The State of Kuwait is located in the northwestern Arabian Gulf. It is characterized by arid to semi-arid weather. This study's concerned with the southern coastal area of the Al-Khiran. The purpose of this study is to evaluate and study the geo-history and evolution of geomorphologic features, especially coastal Ridges and Sabkhas in the Al-Khiran study area. This study based on the field observations as well as the application of Geographic Information Systems (GIS) and Remote Sensing techniques to establish a geodatabase for the study area in different disciplines. The results showed that the Al-Khiran coastal area was affected by the sea level fluctuation and coastal sedimentation during the Holocene and late Pleistocene. The coastal Ridges were originally coastal dunes, which were composed during the sea regression periods and consolidated with time. These Ridges were developed with time and separated the Al-Khiran area as a closed lagoon. This lagoon dried with time and formed a Sabkha field, especially on the depression zone that intersected or surrounded with the coastal Ridges. The Remote Sensing change detection technique shows that the changes were mainly concentrated on covering Sabkhas in some locations and might be due to the impact of active sand sheets and Aeolian sands. Land development in the Al-Khiran area led to the demolition of most of the coastal Ridges and Sabkha deposits.
\end{abstract}

Keywords: Geo-History; Geodatabase; GIS; Remote Sensing; Coastal Ridges; Sabkha; Kuwait; Arabian Gulf

\section{Introduction}

The State of Kuwait has arid to semi-arid weather, with an average annual precipitation of $115 \mathrm{~mm}$, and prevalence of NW winds. Its summer is very hot with a maximum mean temperature of $45^{\circ} \mathrm{C}$ and its winter is very cold [1]. It is located at the northwestern part of Arabian Gulf. It is bordered by the Arabian Gulf from the east, by Iraq from the north and west and by Saudi Arabia from the south. Kuwait lies between latitudes $28^{\circ} 30^{\prime}$ and $30^{\circ} 05^{\prime} \mathrm{N}$ and longitudes $46^{\circ} 33^{\prime}$ and $48^{\circ} 30^{\prime} \mathrm{E}$, with an approximately area of $18,000 \mathrm{~km}^{2}$ [2,3]. In general, the Kuwaiti mainland is characterized by low relief. The higher elevation of $248 \mathrm{~m}$ is located in the western area of Kuwait.

The prevailing wind directions affecting the area are northwesterly, locally known as "Shamal", and southeasterly, locally known as "Kaus". Winds from other directions are less frequent and of shorter duration. The northwesterly winds are dry and cool in winter and hot in summer blowing from the inland desert and prevailing in the winter during the months of December to February and in summer during the months of June to September. They may bring humid air from the Arabian Gulf during the spring and autumn. The means wind speed, which varies with direction and season, is about $4.8 \mathrm{~m} / \mathrm{s}$. Wind speed reaches its maximum during June and July and its minimum during October and November. The average wind speed reaches $6.2 \mathrm{~m} / \mathrm{s}$ during June and $4.1 \mathrm{~m} / \mathrm{s}$ in January [4]. Dust and dust storms (locally known as "Toze") characterize the climate in the area. They are most frequent in summer, particularly in June and July which occupy about $50 \%$ of the total number of dust storm hours, and with a frequency distribution of $75 \%$ of the total number of dust hours during the year [4].

The purpose of this research is to study the geo-history and geomorphological evolution of the coastal Ridges and Sabkhas at the southern part of Kuwait, especially at 
the Al-Khiran study area. Moreover, it aims to study and evaluate the geoenvironmental characteristics of the study area. This research study involved applying Geographic Information Systems (GIS) and remote sensing techniques to document different data sets and mapping the geo-history and main geological setting of the AlKhiran area.

\section{Study Area}

The Al-Khiran study area is located at the southern part of Kuwait, some $100 \mathrm{~km}$ to the south of Kuwait City on the coast of the Arabian Gulf, which is part of the western Mesopotamian shallow shelf. The study area is delineated by latitudes $28^{\circ} 32^{\prime} 05^{\prime \prime}$ to $28^{\circ} 45^{\prime} \mathrm{N}$ and Longitudes $48^{\circ} 15^{\prime} 00^{\prime \prime}$ to $48^{\circ} 26^{\prime} 06^{\prime \prime} \mathrm{E}$ (Figure 1). The northern part of the Arabian Gulf receives sediments coming from the Mesopotamian Rivers. Four conspicuous tidal creeks cut through the Al-Khiran area from top to bottom: Khor Al-A'Ama, which is wide of $1 \mathrm{~km}$ maximum width with a narrow channel that connects it to the open sea; Khor Al-Mufatah, Khor Al-Mamlaha, which are on the contrary narrow creeks; and the small Khor Iskander (Figure 1). These Khors are likely the remains of an active old drainage system from the Würm glaciations. They cut through five sequenced Pleistocene to Holocene oolitic beach/dune Ridges [5]. Dalongeville and Sanlaville [6]; Sanlaville, et al. [7]; and Dalongeville [8] studied the Holocene sea level fluctuations at different sites on the western coast of the Arabian Gulf. As most of Kuwaiti territories, the study area is arid, where the temperature varies widely. The area is characterized of a long, hot, dusty summer extends from May to October; and a relatively short, pleasant winter beginning in November and ending in February, where March and April are transitional between summer and winter.

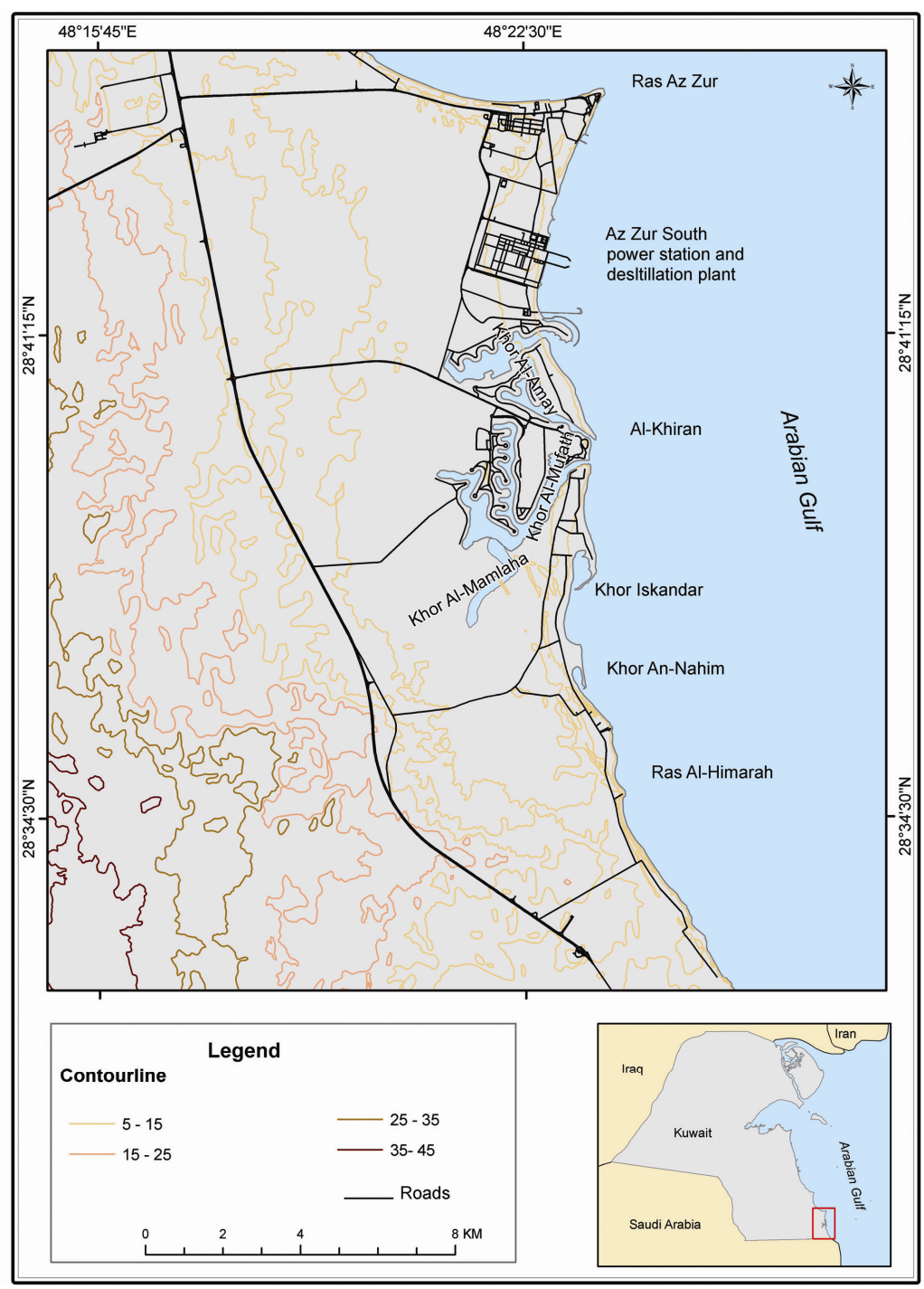

Figure 1. The location map of the Al-Khiran study area. 
During the past decades and among the ambitious attempts to develop the Kuwait's shorelines in general and the southern sector of the shores in particular was the development project named "Al-Khiran Pearl City". The project consists of five phases resulting in a complex lagoon system depending on the tidal inflow from several openings along the Arabian Gulf for water flushing [9].

\section{Methodology}

SuperGIS 3.1 and ArcGIS 9.3 desktop GIS software packages, and ERDAS Imagine 9.1 remote sensing software were used to carry out this study. Spectral enhancement techniques, such as contrast stretching (Linear, Gaussian and Histogram Equalization) were carried out using ERDAS imagine to enhance the visual interpretation of the study area from the available satellite images, such as Landsat and IKONOS scenes. The available topographic maps of scale $1: 100,000$ and 1:50,000 are scanned, georeferenced into UTM map projection (zone 39) and WGS84 datum and spheroid, then converted into vector digital format and stored in Geodatabase using the selected GIS packages. In addition, the different landforms in the study area are delineated and classified from the high resolution IKONOS image acquired on August 2010 for the study area. The Landsat images dated 1990 and 2003 are used to study the coastal Sabkhas development with time. Different thematic maps are prepared with the help of field investigation of the study area. In addition, the Digital Terrain Model is produced from the contour lines of the topographic map of scale 1:50,000.

\section{Geo-Environmental Characteristics}

\subsection{Geomorphology}

The land surface of Kuwait is generally flat and occasionally interrupted by low hills, scarps, valleys of ephemeral streams and shallow wide inland depressions. The altitude rises from sea level to about $300 \mathrm{~m}$ in the southwestern part of Kuwait. It slopes gradually northeastward with an average gradient of $2 \mathrm{~m} / \mathrm{km}$.

The coast of southern Kuwait is characterized by numerous coastal Ridges ranging from 5 to $15 \mathrm{~m}$ high comprising both marine and Aeolian sediments represented by recent and old beaches, barriers and coastal dunes [10]. These features are composed of oolitic sand, sandstone and limestone. Landward, the coastal flat is occupied by widespread, low-lying and extremely flat Sabkhas, separated from the open sea by the above-mentioned Ridges [10-12]. The inland margins of these Sabkhas are partially covered by Aeolian sands and so the Sabkhas grade laterally into higher coastal sandy plain. The southern intertidal zone of Kuwait is an open marine environment marked by a relatively steep beach profile and a narrow rocky tidal flat partially covered by sand $[13,14]$, with medium to coarse oolite grains in the AlKhiran area [15]. The intertidal flat becomes wider along the Al-Khiran to An-Nawasib coast and is dominated by tides and characterized by gently inclined mudflats bounded landward by extensive supratidal Sabkha flats [16,17].

According to Al-Sulaimi and El-Rabaa [18], the land surface of the study area is classified into three geomorphic zones where changes in relief occurred (Figure 2). These are: the coastal flat zone (zone 1) composed of coastal Ridges, followed by the depression zone (zone 2) then the more rugged zone (zone 3) landward in southern coast of Kuwait [19]. The coastal zone is characterized by $5-15 \mathrm{~m}$ high Ridges of oolitic and calcareous sandstone sediments; the depression zone is composed of flat Sabkhas; the rugged zone contains some high and low relief features. The Sabkha depression (zone 2) is a structural feature formed in between the Ridges and parallel to the coastline, with a width increasing at the Al-Khiran area where the Khors are formed. Different Aeolian sediments such as sand sheets are accumulated in this depression [19].

The Al-Khiran area is made up of complex tidal inlets and lagoons, with adjacent Sabkha, showing a wide range of salinities and substrate types [20]. It is cut by conspicuous tidal creeks, called "Khor" from which the area took its name "Khiran" the plural of "Khor". They represent a diverse ecosystem consisting of five creeks: from south to north: at the southernmost inlets Khor Iskandar and Khor An-Nahim, which are comparatively small and directly open to the sea, Khor Al-Mamlaha, Khor Al-Mufatih, and Khor Al-'Amay in the north (Figure 1). Khor Al-Mufatih and Khor Al-Mamlaha comprise a branching system of narrow creeks of an average width of $0.75 \mathrm{~km}$ extending landwards for about $5.5 \mathrm{~km}$ connected to the sea by a single narrow channel, which may indicate their being of the remains of an old active drainage system in the area during the Würm glaciation. Khor Al-'Amay is a wide tidal creek of maximum width of $1 \mathrm{~km}$ and a narrow channel at its connection with the open sea $[5,20]$. These Khors cut through a sequence of five Pleistocene to Holocene, oolitic, beach/dune ridge formulating a band of highland of $3 \mathrm{~km}$ wide, rarely reaches $15 \mathrm{~m}$ elevation above sea level. The Ridges surround a wide coastal plain covered by Sabkhas, which in their turn surround both ends of the Khor Al-Mufatih and Khor Al-Mamlaha system, at the northernmost limit of the anhydrite-bearing Sabkha evaporate belt in the Gulf at latitude $29^{\circ} \mathrm{N}$, whereas Sabkhas north of this latitude totally empty of anhydrite [5,20]. The tidal flats in the area are relatively wide and cut by a narrow sub-tidal channel of about $7 \mathrm{~m}$ maximum deep at low tide. The tidal amplitude may reach $1.5 \mathrm{~m}$ at the mouths of the 


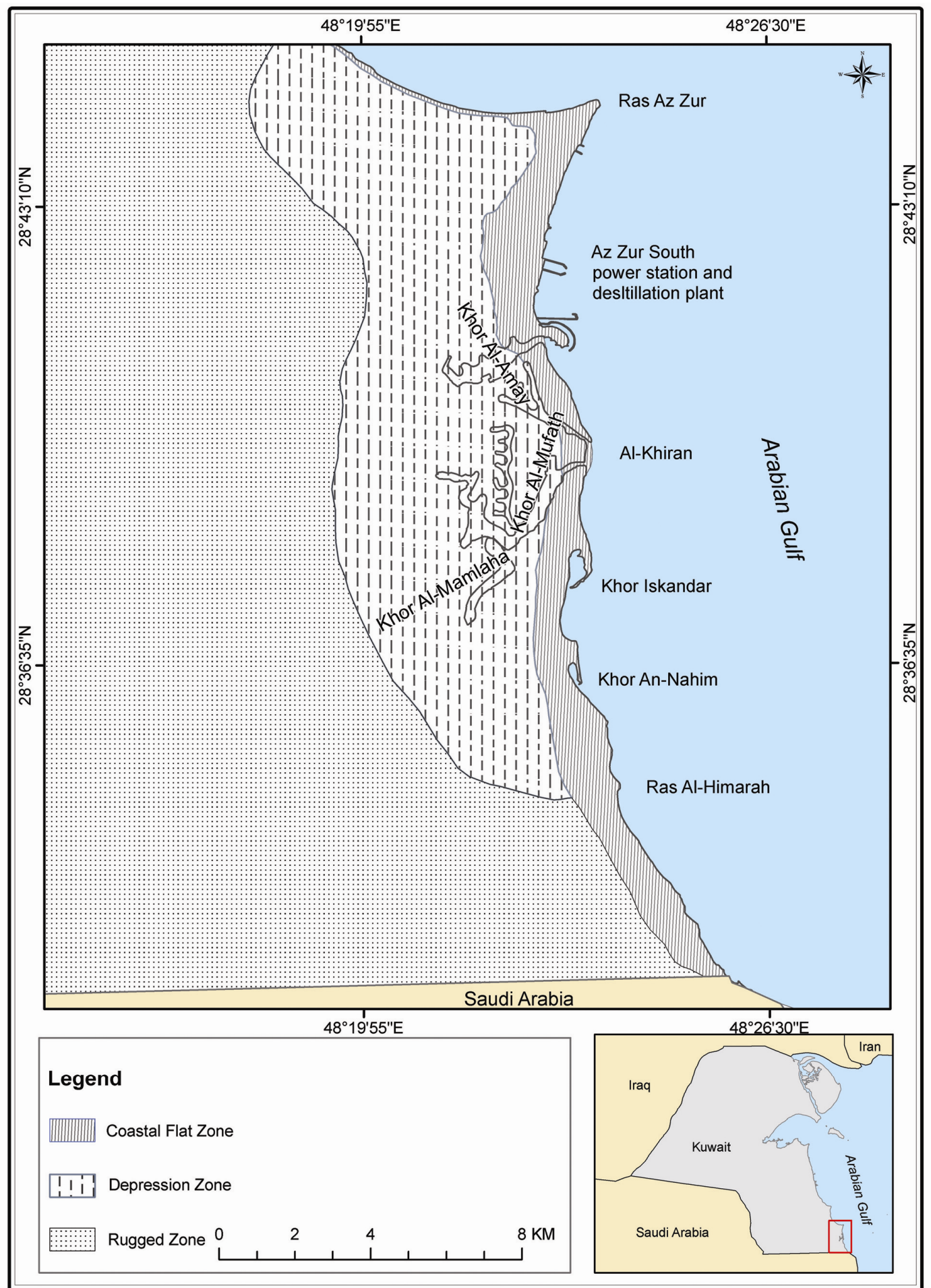

Figure 2. Geomorphic map showing the three classified geomorphic zones of the Al-Khiran area.

creeks. Khor Al-Mufatih is mainly sandy substrate at its mouth changing gradually to muddy sand and then mud landwards. The conditions within the Khors are hypersaline due to the high rate of evaporation and low incoming flow of fresh water, which is clearly indicated in Khor Al-Mufatih having a salinity range from $40 \mathrm{ppt}$ near the sea to $120 \mathrm{ppt}$ at the extreme inland end of the Khor [20].

Sabkha deposits cover wide low areas which are extremely flat and usually barren of vegetation. The AlKhiran Sabkha formed under the influence of saline groundwater and mostly flooded in most places, espe- 
cially in west of the two channels where the main largest Sabkha is found. Some isolated small Sabkhas also fill the shallow deflational depressions between Ridges. The Sabkha deposits are composed essentially of quartz sand of variable sizes, mixed with carbonate mud and scattered crystals of gypsum [19].
The change detection technique was applied to monitor the changes that happened in the study area from 1990 through 2003 using Landsat images. It was observed that there were some changes in the landforms and distribution of surface sediments types in the study area. Figure 3 illustrates the changed areas along the

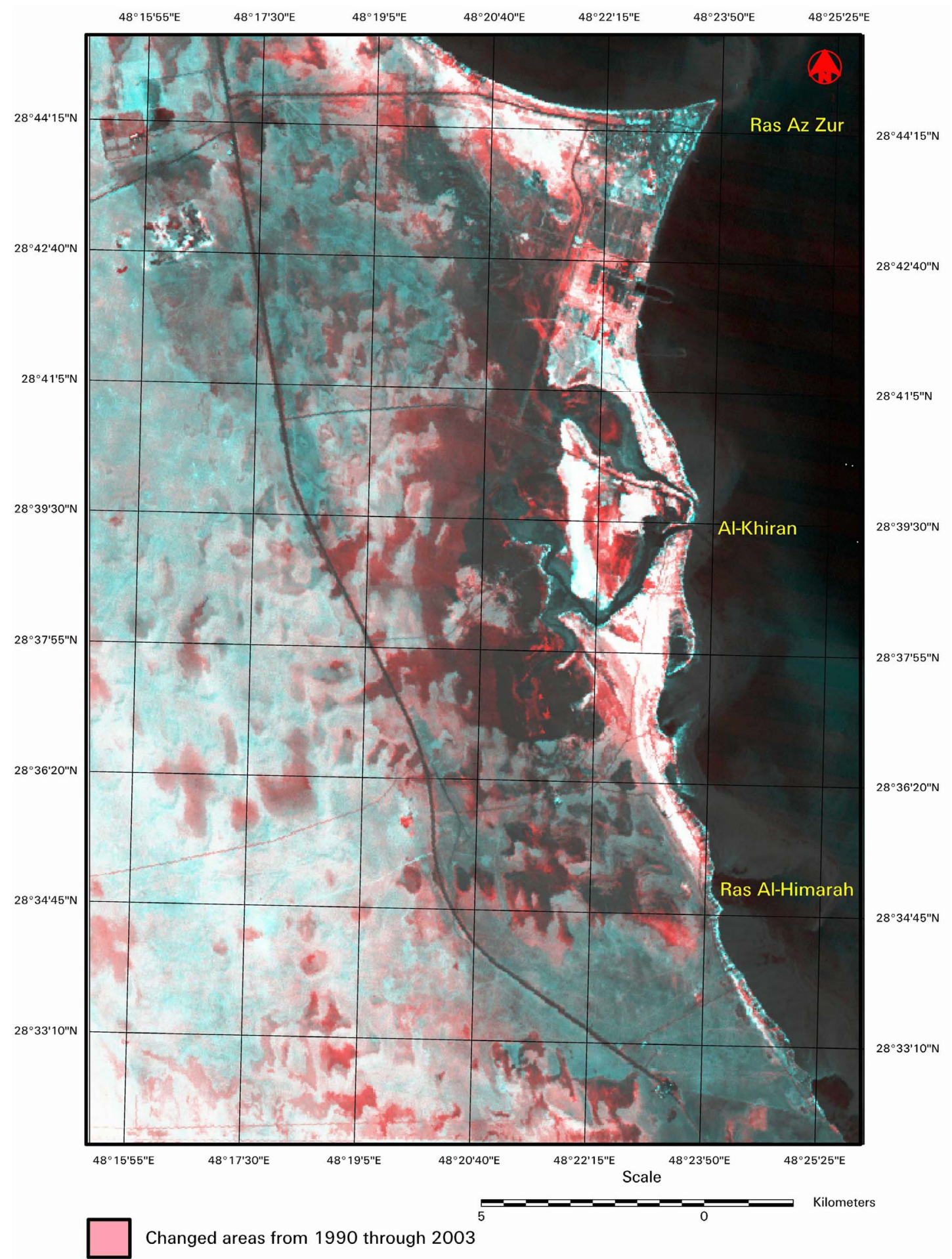

Figure 3. Change detection from 1990 through 2003 based on LANDSAT images. 
coastal zone of the Al-Khiran area during 13 years, from 1990 (Landsat TM) through 2003 (Landsat ETM+). The light red color represents the changes that happened in the study area from 1990 until 2003. It was noticed that there were many changes occurred either on Sabkha habitats or the surface sediments. The changes were mainly due to the changes in the nature of Sabkhas from wet to dry or vice versa, or due to the movement of active sand sheets (sand drifts) that may cover Sabkha deposits in some places.

\subsection{Sedimentology and Mineralogy}

The surface of Kuwait is covered by Quaternary sediments that include Pleistocene gravel and sand and Holocene sediments including marine sand, coastal deposits, beach rocks, Sabkha deposits, desert floor deposits, alluvium and Aeolian sands [12,21]. Aeolian deposits are the most frequent surface types in Kuwait. Four types were recognized: sand sheet, sand dunes, sand drifts, and Aeolian wadi fill [12].

Oolitic limestone and sands with varying content of oolites are found along the southern coast of the country. These sediments are well represented in the Al-Khiran area, where they constitute parallel Ridges and low cliffs of slightly to moderately consolidated oolitic limestone. The sediments of the Al-Khiran area were found to be composed primarily of carbonates with subordinate amounts of quartz, feldspars, and clay minerals [22,23]. Several oolitic Ridges are presented to the south along the coastline of the study area, which were deposited during Quaternary fluctuations in sea level [11]. According to Al-Hurban and Gharib [19], the Sabkha deposits in the area are mainly composed of quartz feldspar, rock fragments, calcareous grains, and gypsum.

Most of the sediments of the tidal creeks of Khor Al-Mufatih and Khor Al-Mamlaha are marine carbonates coming from the calcareous mud, skeletal fragments, ooids and pellets. Except those in the calcareous mud constituent, the marine carbonates are autochtonous (i.e. formed in situ), as those of calcareous mud constituent may be partly transported by tidal currents from the sea into the creeks [24]. At the end of the creeks, minor Aeolian particles are found mixed with silty and clayey sediments brought by dying tidal waves. The Aeolian sand sized sediments are rare in and around the tidal creeks. The major factors of transporting sediments in the creeks are first the tidal currents and then the wind generated winds. The coarser sediments are found in the channels and finer sediments are accumulated landwards in the tidal flats and at the landwards end of the major channels. In the tidal flats, the parts of the upper intertidal reah are regarded zones of sediments lithification leading to the development of lithified sediments or crusts. This is because these parts are exposed to strong tidal currents or poor supply of sediments [24]. Comparing the sedimentomorphic map with the same type of map of Khalaf et al. [12], it is found that most of the Sabkha deposits increased in size and spread towards west direction (Figures 3 and 4). The field observations showed that most of the smooth sand sheet is now covered with vegetated sand sheet.

\subsection{Hydrogeological Aspect}

The subsurface water flow system beneath the Sabkah is part of a regional seaward flowing groundwater regime. The water table depth below the Sabkha surface increases landwards. The water table below the Sabkha surface is sloping seaward revealing that groundwater flow in the area is directed seaward. As directing seawards in the Sabkhas the downward flow of water predominates the seaward direction flow of groundwater. This is due to the infiltration and percolation of water from the shallow water bodies of seawater that are pushed landwards over the Sabkha surface by strong onshore winds [25]. On the other hand as directing landwards, where no marine flooding occurs, the downward flow is directed upward as a reaction against the evaporation at the Sabkha surface. The development of Sabkhas (broadness and thickness of sedimentary facies) is influenced by the sea level fluctuation. Figure 5 illustrates the Sabkha deposits extracted from high resolution IKONOS satellite images with spacial resolution of $1 \mathrm{~m}$, dated August 2010. Sabkha deposits were then overlaid with the digital elevation model of the study area.

There are two types of Sabkhas namely wet and dry. Most of wet Sabkha are concentrated to the east on the depression zone and closed to the beach. The dry Sabkhas are concentrated to the west while the surfaces of the surface sediments were increased. It seems also that wet Sabkha are connected somehow, especially on high or very high tides to the Khors in the study area. The source of wetness could be from the flooding coming out from western high elevation lands or from the Gulf water intrusion to the depression, especially when the water table in the depression become more deeper. Figure 6 illustrates the Sabkha deposits that extracted from the enhanced IKONOS satellite image of August 2010 , overlaid with the depth of ground water from the surface of the study area. The wetness of Sabkha in the depression zone may also be due to the shallowness of the water table in this area. This argument should be reviewed and validated in the field.

The natural drainage pattern at the Al-Khiran area is a simple dendritic pattern with channels increasing in width and depth toward the sea, an estuarine basin exceeding 500 hectares, and a small normal area of open 


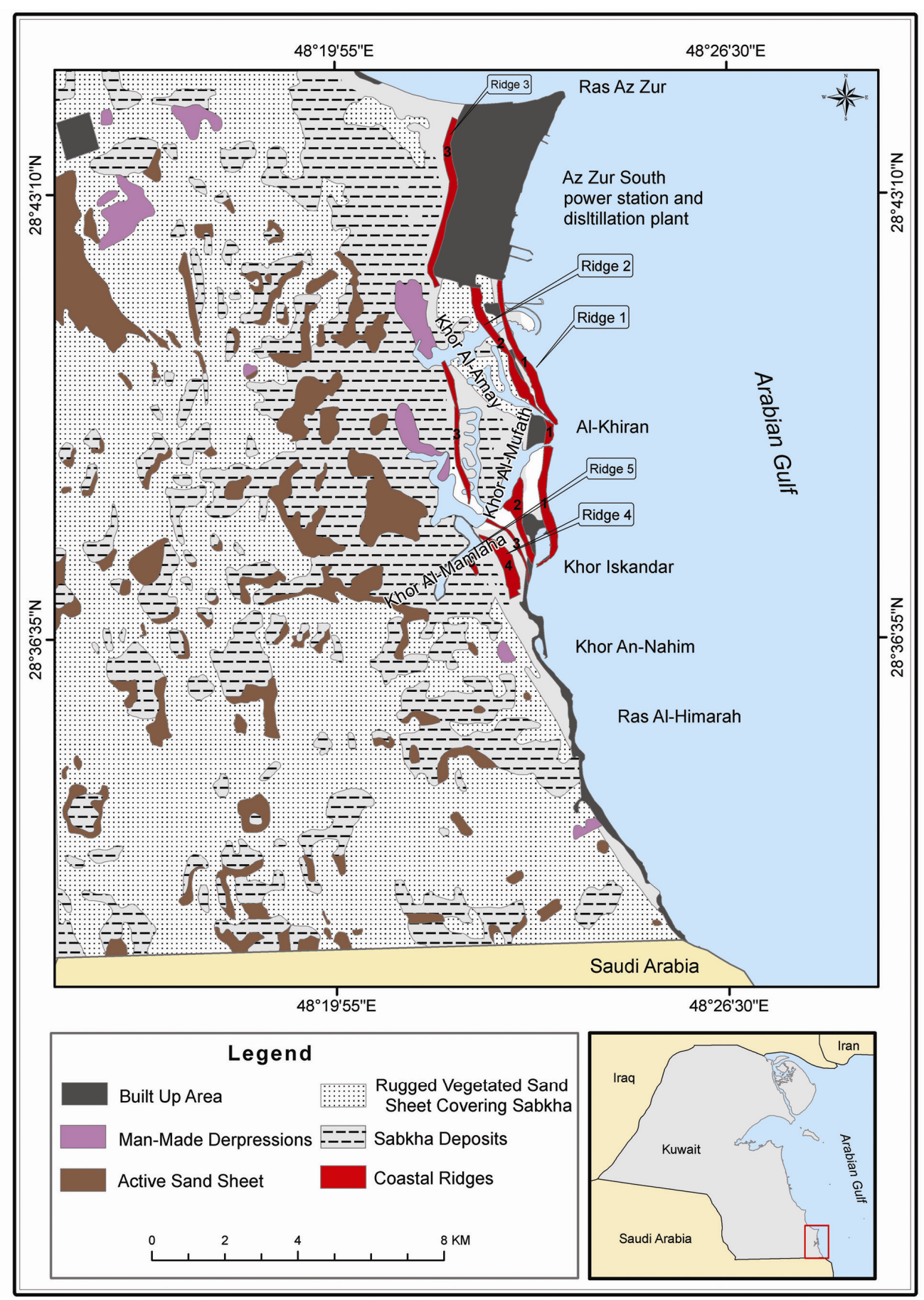

Figure 4. The sedimentomorphic map of the Al-Khiran area.

water. The two entrance channels are less than $50 \mathrm{~m}$ wide, $1 \mathrm{~m}$ deep at low tide and handle tidal priosms of the order 100,000 cubic meters [26].

\section{Geo-Historical Evolution of Coastal Ridges and Sabkhas in the Al-Khiran Area}

The geomorphological development and evolution of the
Al-Khiran area was affected by the local fluctuation in the sea level and coastal sedimentation during the Holocene and late Pleistocene. Fairbridge [27] and Kassler [28] stated that the Gulf region was land instead of sea during the Würm or last glacial age $(70,000-17,000 \mathrm{BP})$ as the sea levels were 100 to $120 \mathrm{~m}$ lower than the current time and the maximum depth of the Arabian Gulf did not reach $100 \mathrm{~m}$. Hence, the Arabian Gulf basin must 


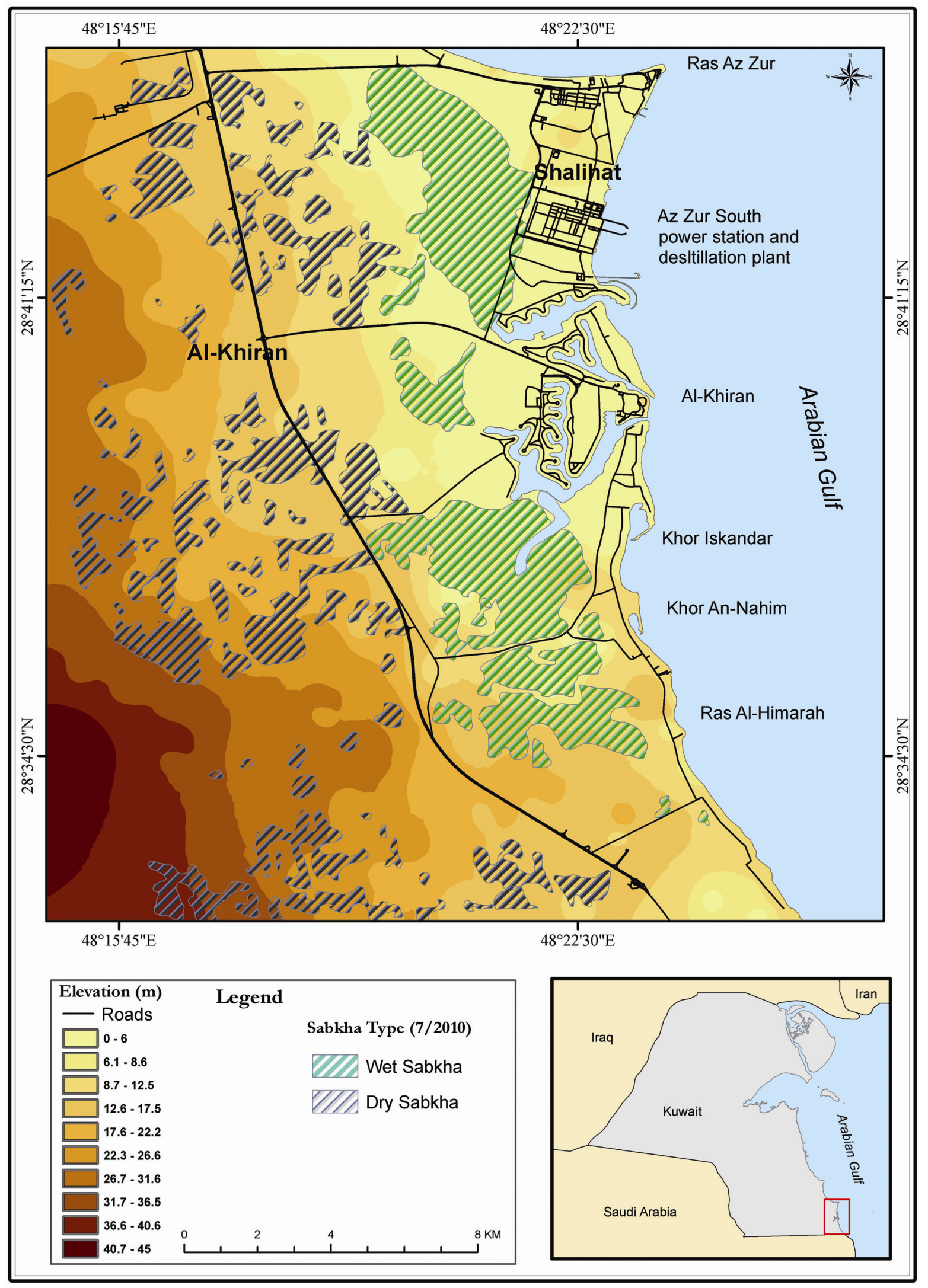

Figure 5. Digital elevation model overlaid with Sabkhas, extracted from IKONOS satellite images dated August, 2010 in the Al-Khiran area. 


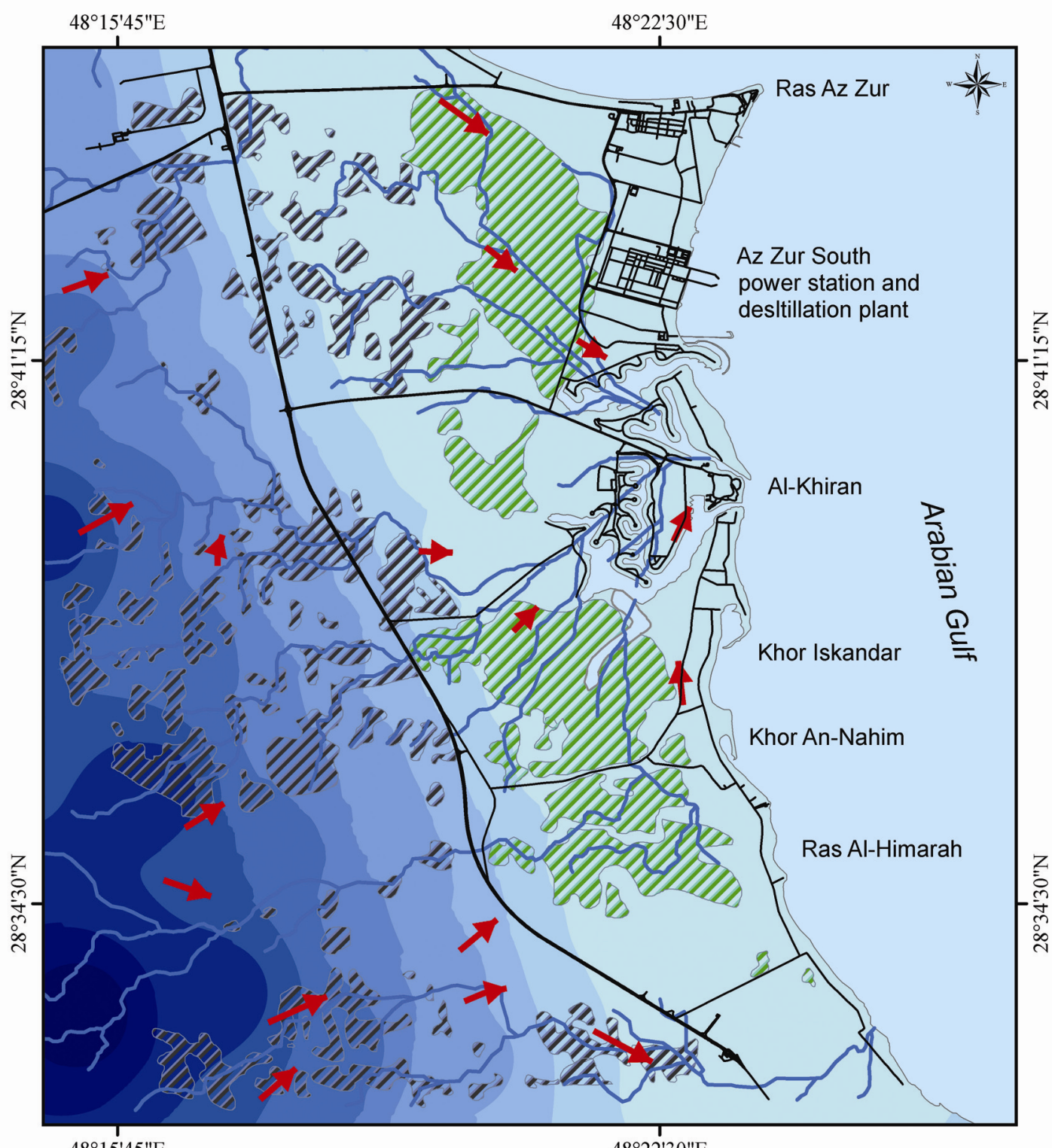

$48^{\circ} 15^{\prime} 45^{\prime \prime} \mathrm{E}$

$48^{\circ} 22^{\prime} 30^{\prime \prime} \mathrm{E}$

\begin{tabular}{|c|c|c|}
\hline $\begin{array}{l}\text { Legend } \\
\text { Roads }\end{array}$ & \multicolumn{2}{|c|}{$\begin{array}{l}\text { Water Depth } \\
(\mathrm{m} / \mathrm{msl})\end{array}$} \\
\hline Runoff direction & $-60--55$ & $-34--30$ \\
\hline - Wadis & $-54--50$ & $-29--25$ \\
\hline & $-49--45$ & $-24--20$ \\
\hline Sabkha Type $(8 / 2010)$ & $-44--40$ & $-19--15$ \\
\hline $\begin{array}{l}\text { Wet Sabkha } \\
\text { UIA Dry Sabkha }\end{array}$ & $-39--35$ & $-14--10$ \\
\hline $\begin{array}{l}0 \\
1\end{array}$ & 1 & \\
\hline
\end{tabular}

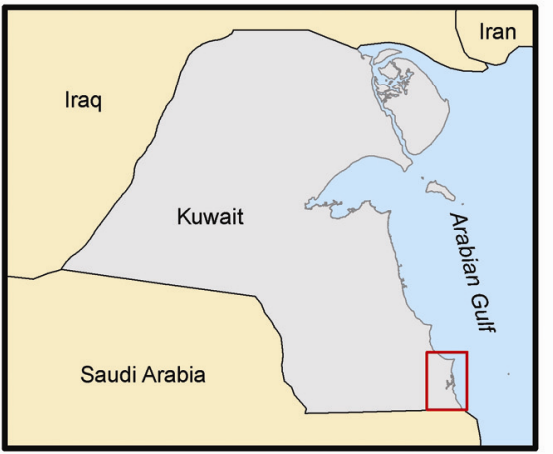

Figure 6. Groundwater depth overlaid with Sabkhas, extracted from IKONOS satellite images dated August, 2010 in the Al-Khiran area. 
have been land drained due to the prolongation of Shatt Al-Arab waterway emptying in the Gulf of Oman. According to Beard, et al. [29], the sea level during the Wisconsin glaciation (Woodfordian) was only $90 \mathrm{~m}$ lower than the present level reaching its peak 18,000 years ago followed by gradual rise resulted in a general transgression over most of the world, which is known as the Holocene Flandrian transgression. Stoffers and Ross [30]; Al-Asfour [31]; Dalongeville and Sanlaville [6]; and Dalongeville [8] recognized on the coasts of the Arabian Gulf. Dalongeville and Sanlaville [6] stated that the Holocene transgression reached close to the present shores in the Arabian Gulf region 8000 - 7000 years ago proceeding in several steps shown in the sea-floor topography of the Arabian Gulf by six conspicuous submerged terraces of different levels: $120 \mathrm{~m}, 100 \mathrm{~m}, 66$ $80 \mathrm{~m}, 29-27 \mathrm{~m}, 18 \mathrm{~m}$ and $9 \mathrm{~m}$ below the current sea level [28]. Probably the $100-120 \mathrm{~m}$ (the lowermost) below the current sea level is within a low-stand of seal level older than Woodfordian or witnessing tectonic subsidence of the Gulf's floor. Dalongeville and Sanlaville [6] reported that upon the level of the present-day, coast was approximately reached; the Holocene sea in Kuwait went through several minor oscillations around the current sea level, where three peaks were major: 6000 year BP, 4500 year BP and at 3000 year BP, separated lowstand of sea level phases. One of these phases was at 2000 year BP. The sea level since these peaks and phases of low-stand of sea level had rise to its present level, where all such fluctuations recorded only amplitude of 2 $\mathrm{m}[8]$.

Conclusively, the late Pleistocene and Holocene sediments of the Al-Khiran area reveals mostly the major sea level fluctuations of the Arabian Gulf in the last 8000 years. Some 26,650 years ago during the Woodfordian phase of low sea level stand in which the oldest exposed sediments (continental deposits) of limited extent lay down. Those sediments contained high siliciclastic component suggesting wetter climate than the today's climate, which is consistent with the Arabian Peninsula was covered by savannahs during the Plaeolithic [32]. Those continental deposits are overlain by a coastal dune with considerable amount of siliciclastic grains with oolites assuring the continuation of relatively wet climate. Such dunes represented the latest warm episode before the large-scale Würm glaciation leaving the Arabian Gulf as dry land [32].

In the Al-Khiran area four Chenier coastal dunes represent the Holocene sediments and are pointing out to the phases low sea level stand during the Flandrian transgression, where the highest peak of the same transgression is older than all these phases, recognized by a line of coastal erosion resulted in burrows of organisms, affecting seaward side of the fifth pre-Flandrian coastal ridge
[5]. The Holocene sediments of the Al-Khiran area are in low content of siliciclastic component denoting arid climates resembling the today-predominating ones. The phases of the high sea level stands of Flandrian transgression had witnessed the sedimentation of mainly intertidal or subtidal deposits rich in marine shells and usually present at the foot of the coastal Ridges. Figure 7 shows the entire above illustrated event in the Al-Khiran area [5].

Figure 8 shows the evolution of the coves in the Al-Khiran area due to refilling of the existing coves as a result of the prolonged sedimentation regime in the area. This figure simulates the evolution of the coastal Ridges and coastal Sabkha in the Al-Khiran area. This simulation was proposed based on the following facts:

- The Al-Khiran as a coastal area on the border of Arabian Gulf basin consequently could be affected by the tectonic and geomorphic processes during its development that took place during the late PliocenePleistocene [28,33].

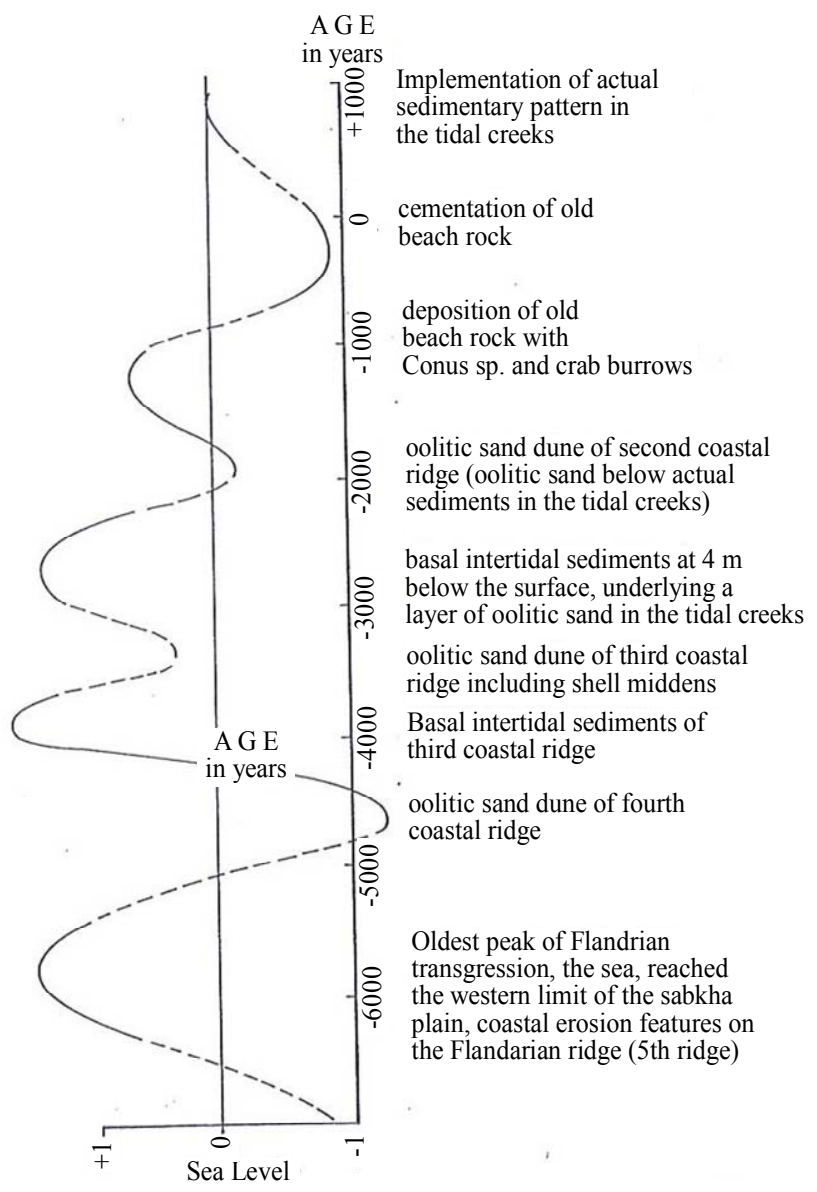

Figure 7. Diagram showing the relation of some prominent sedimentary and geomorphic features of the study area with major fluctuations of the Flandrian Sea recognized by Dalongeville (1990) in western coasts of the Arabian Gulf (after Al-Sarawi, et al., 1993). 

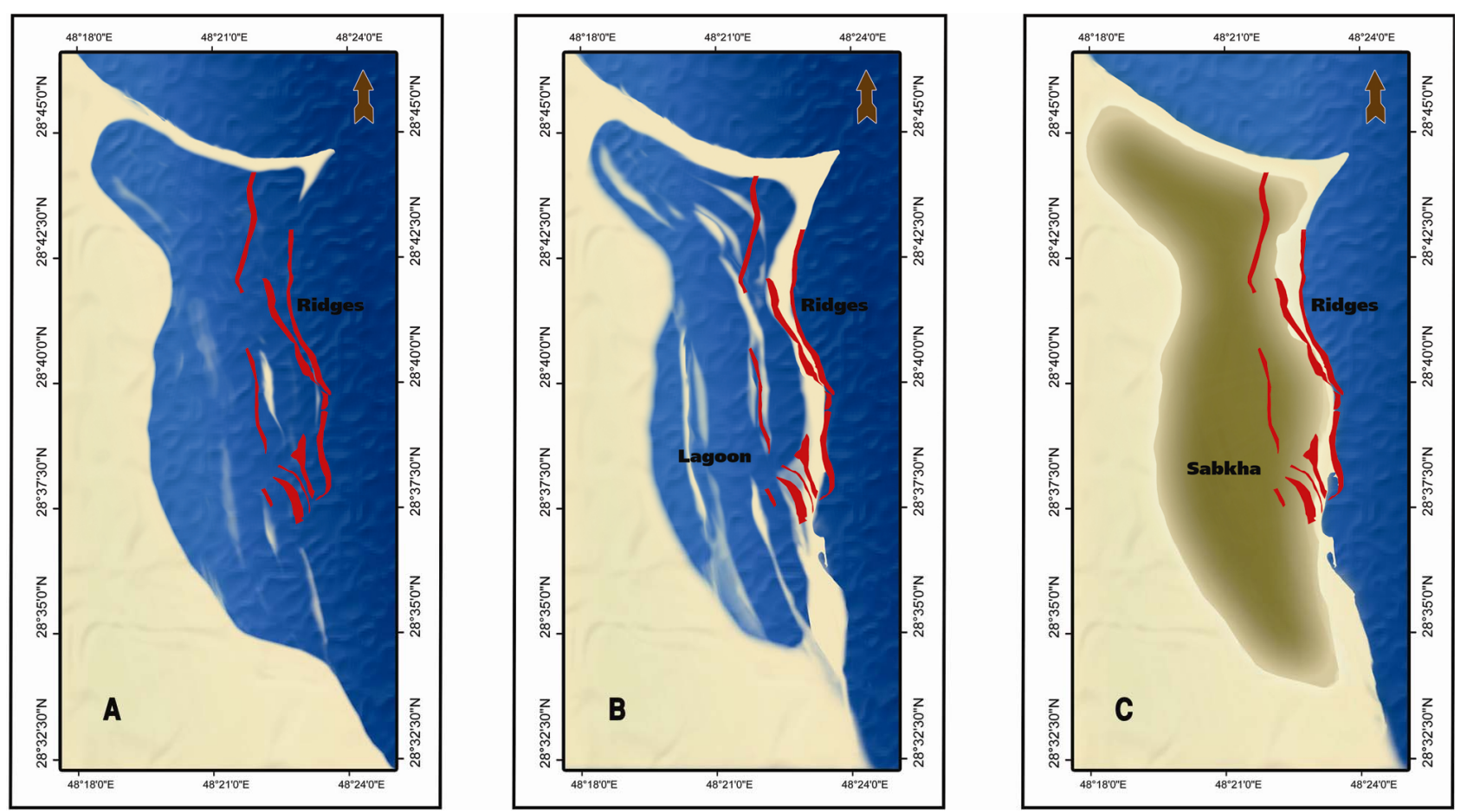

Figure 8. The evolution of the coves in the Al-Khiran area due to refilling of the existing coves as a result of the prolonged sedimentation regime in the area.

- The evolution of the Al-Khiran coastal area was basically affected by the fluctuation of the sea level and movement of coastal sediments during the Holocene and late Pleistocene. It was affected by many factors as follows:

- The periods of sea transgressions and regressions due to the eustatic fluctuation of sea level because of the alternating glacial and interglacial episode.

- The neotectonics by which many parts of the Arabian Gulf were affected because it is lies along a subduction zone between two continental phases.

- The coastal marine current and its effect on the marine coastal sediments movement and deposition.

- During the regression period, the Al-Khiran coastal area was affected by the arid condition of the desert in terms of movement of active sand sheets into the depression zone and the precipitation of Aeolian sands. This was lead to development of number of elongated sand dunes that became later on the base for most of coastal Ridges in this area.

- During the transgression periods, the accumulated and developed coastal dunes at the Al-Khiran area acted as coastal barriers against the marine transgression on this area.

- The development of these coastal Ridges and barriers were continued during the two phase of transgression and regression, either by adding marine sediments due to the current effects or due to the precipitation of Aeolian or drifting sand.
Over time, these coastal Ridges acted as coastal barriers and grew to isolate the Al-khiran area, eventually becoming a closed lagoon. This lagoon dried with time and added to the main land as a Sabkha field intersected with some coastal Ridges (Figure 8).

The previous illustrated scenario of the evolution of the Al-Khiran coastal area could be approved and understood by the development of the Tanajib-Al-Khawwari head land at the north-eastern coast of Saudi Arabia (Figure 9). The successive head lands that parallel to the shoreline are developing with time. Once the head land attached with the main land or another head land coming from the opposite side, this will cut part of the marine environment as a lagoon. With time and due to arid nature of the area, the lagoon became dry and receive sediments from different sources and change into coastal Sabkha in Figure 9 we can see the developed Sabkha to the west in dark color and parallel the existing head land barriers that surrounding a semi-closed lagoon to the east that will be closed lagoon with time and become dry and change into coastal Sabkha.

The analysis of recent high resolution satellite images and the recent field observations showed that most of the coastal Ridges were demolished due to the new urbanization and development in the Al-Khiran area. Also, the Sabkha deposits, especially on the middle of the AlKhiran study area was demolished due to the rapid urbanization in the area. If the urbanization of this area continued, the remains of Sabkhas and coastal Ridges 


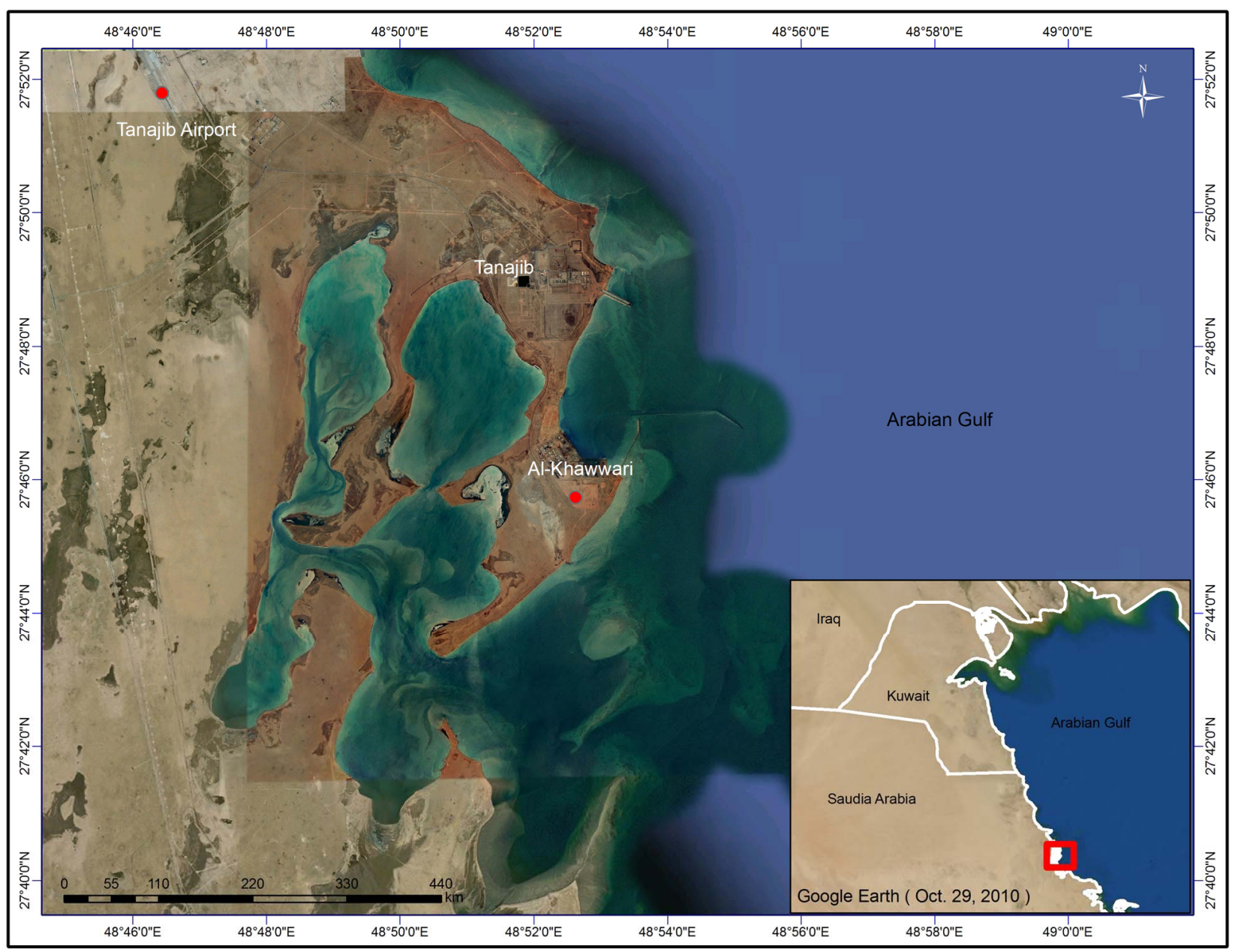

Figure 9. Ras Tanajib-Al Khawwari, north-eastern coast of Saudi Arabia.

will be totally disappeared. The study area seems to be highly vulnerable to any expected sea level rise due to the global warming issue.

\section{Conclusions}

Aeolian sand sheets deposits are the most frequent recent surface deposits in Kuwait, and cover most of the other sediments. The direction of movement of the sand sheets is from NW-SE according to the direction of prevailing winds. Sabkhas were subjected to invasion by sand sheets that were caused by the NW winds, which make these a blanket of sand as a cover to Sabkhas.

Late Pleistocene and Holocene sediments of the Al-Khiran area are indicators of major fluctuations of the sea level of the Arabian Gulf in the last 8000 years. Moreover, the high siliciclastic content of the sediments may lead to wetter climatic conditions than the nowadays prevailing. The coastal Ridges were developed mainly during the regression period of sea level. The development of those Ridges separated the Al-Khiran area into a closed lagoon that dried later over time to develop cur- rent study area.

It has became clear from the analysis of multi-date satellite images that the implementation of the Al-Khiran Pearl City would eliminate the main natural features, especially the only salt marsh (Sabkha habitats) in the southern sector of Kuwait, as well as the coastal Ridges. The elimination and demolishing of the coastal Ridges in addition to the flat and low land nature of the Al-Khiran coastal area will change its nature into a highly vulnerable coastal area due to the global warming scenarios and potential sea level rise.

\section{Acknowledgements}

This work was conducted as part of a project sponsored by Kuwait Foundation for the Advancement of Sciences (Project KFAS 2001-140-102). Special thanks are due to the Geoinformatics Center at Kuwait Institute for Scientific Research (KISR) for their support in producing the needed maps and processing of satellite images. The authors are grateful to the Earth and Environmental Sciences Department, Faculty of Science, Kuwait University, 
for providing the needed support. Special thanks are due to Prof. Rao Divi, Mr. Ismail Gharib, Mr. Nabeel Adeeb, Mr. Mohammed Sami, Mr. Ahmed Abdi and Mrs. Nehaya Saied.

\section{REFERENCES}

[1] M. Koch and F. El-Baz, "Identifying the Effects of the Gulf War on the Geomorphic Features of Kuwait by Remote Sensing and GIS," Photogrammetric Engineering \& Remote Sensing, Vol. 64, No. 7, 1998, pp. 739-747.

[2] J. M. Al-Awadhi, S. A. Omar and R. F. Misak, "Land Degradation Indicators in Kuwait," Land Degradradation Development, Vol. 16, No. 2, 2005, pp. 163-176. doi:10.1002/ldr.666

[3] F. El-Baz and M. Al-Sarawi, "Atlas of the State of $\mathrm{Ku}-$ wait from Satellite Images," Kuwait Foundation for the Advancement of Sciences (KFAS), Cantz, 2000, 145 pp.

[4] F. I. Khalaf and D. Al-Ajmi, "Aeolian Processes and Sand Encroachment Problems in Kuwait," Geomorphology, Vol. 6, No. 2, 1993, pp. 111-134.

[5] M. A. Al-Sarawi, A. Al-Zamel and I. Al-Rifaiy, "Late Pleistocene and Holocene Sediments of the Khiran Area (South Kuwait)," Kuwait Journal of Science-Kuwait University, Vol. 20, No. 1, 1993, pp. 145-156.

[6] R. Dalongeville and P. sanlaville, "Variations Relatives du Niveau Marin du Golfe Persique," In: O. Aurenche, J. Evin and F. Hours, Eds., Chronologies in the Near East, CNRS International Symposium, Lyon, BAR International Series, Vol. 379, 1986, pp. 568-580.

[7] P. Sanlaville, R. Dalongeville, J. Evin and R. Passkof, "Modification du Tracé Littoral sur la Cote Arabe du Golfe Persique en Relation avec l'Archeologie," Colloques Internationaux CNRS, Deplacements des rivage en Mediterranée, Editions du CNRS, Paris, 1987.

[8] R. Dalongeville, "Présentation Physique Général de l'ile de Failaka," Failaka, fouilles Français 1986-1988, Travaux de la Maison de l'Orient 18, Lyon, Paris, 1990, pp. 23-39.

[9] K. A. Rakha and F. Al-Hulail, "Monitoring and Modeling of Phase-A1 for Al-Khiran Pearl City Lagoon System, South of Kuwait," Kuwait Journal of Science and Engineering, Vol. 33, No. 1, 2006, pp. 71-81.

[10] F. Picha, "Depositional and Diagenetic History of Pleistocene and Holocene Oolitic Sediments and Sabkhas in Kuwait, Persian Gulf," Sedimentology, Vol. 25, No. 3, 1978, pp. 427-450.

doi:10.1111/j.1365-3091.1978.tb00320.x

[11] A. A. M. Saleh, "Pleistocene and Holocene Oolitic Sediments in the Al Khiran Area," M.Sc. Thesis, Kuwait University, Kuwait City, 1975.

[12] F. I. Khalaf, D. Al-Bakri and A. Al-Ghadban, "Sedimentological Characteristic of the Surficial Sediments of the Kuwaiti Marine Environment, Northern Arabian Gulf," Sedimentology, Vol. 31, No. 4, 1984, pp. 531-545. doi:10.1111/j.1365-3091.1984.tb01818.x

[13] F. I. Khalaf, "Geology and Mineralogy of the Beach Sediments of Kuwait,” M.Sc. Thesis, Kuwait University,
Kuwait City, 1969.

[14] Dames and Moore, "Hydraulic Studies for Sabiya Area, Kuwait Bay and the Development of Electrical Networks 2 Vols," Report No. MEW/cp/gp-1113-801/81, The Ministry of Electricity and Water, Kuwait, 1983.

[15] I. M. Ali, "Coastal Geomorphology and Beach Stability along Al-Khiran Area, Kuwait," Master Thesis, Kuwait University, Kuwait City, 1994, 163 pp.

[16] D. H. Al-Bakri, W. Shublaq, A. Al-Ghadban, Z. Al-Sheikh and W. Kittaneh, "Preliminary Study of the Physical and Biological Aspects of the Kuwait Coastal Zone (EESGEN)," Report No. KISR1038, KISR, Kuwait, 1983.

[17] D. H. Al-Bakri, M. Foda, M. Behbehani, F. I. Khalaf, W. Shublaq, M. I. El-Sayed, et al., "Environmental Assessment of the Intertidal Zone of Kuwait," Report No. EES35, Kuwait Institute for Scientific Research (KISR), 1985, $413 \mathrm{p}$.

[18] J. S. Al-Sulaimi and S. M. El-Rabaa, "Morphological and Morphostructural Features of Kuwait," Geomorphology, Vol. 11, No. 2, 1994, pp. 151-167. doi:10.1016/0169-555X(94)90079-5

[19] A. Al-Hurban and I. Gharib, "Geomorphological and Sedimentological Characteristics of Coastal and Inland Sabkhas, Southern Kuwait," Journal of Arid Environment, Vol. 58, No. 1, 2004, pp. 59-85.

[20] D. A. Scott, "A Directory of Wetlands in the Middle East," IUCN, Gland, Switzerland and IWRB, Slimbridge, 1995, $560 \mathrm{pp}$.

[21] Hunting Geology and Geophysics (HGG), "Photographical Survey of the State of Kuwait," Submitted to the Kuwait Oil Company (KOC), Kuwait, 1981.

[22] A. Al-Zamel and F. I. Khalaf, "Tidal Flat and be Sedimentation in the Northern Region of Arabian Gulf, Ras Al-Sabbiyah, Kuwait," Fifth Iraqi Geological Congress, Baghdad, 28-31 December 1978, (Abstract).

[23] F. I. Khalaf and M. Ala, "Mineralogy of the Recent Intertidal Muddy Sediments of Kuwait, Arabian Gulf," Marine Geol., Vol. 35, No. 4, 1980, pp. 331-342. doi:10.1016/0025-3227(80)90124-3

[24] O. H. Cherif, I. A. Al-Rifaiy and A. Al-Zamel, "Sedimentary Facies of the Tidal Creeks of Khor Al-Mufateh and Khor Al-Mamlaha, Khiran Area, Kuwait," Scientific Journal of Kuwait University, 1994, 21 pp.

[25] R. J. Patterson and D. J. Knisman, "Formation of Diagenetic Dolomite in Coastal Sabkhas along the Arabian Gulf," Bulletin of the American Association of Petroleum Geologists, Vol. 66, No. 1, 1982, pp. 28-43.

[26] T. W. Kana, B. J. Baca and S. J. Siah, "Chalets at Dubaiyeh, Environmental Impact and Coastal Engineering Studies," Final Report to Kuwaiti Engineers Office, CSE, Columbia, 1986, 102 pp.

[27] R. W. Fairbridge, "Eustatic Changes in Sea Level," Physics and Chemistry of the Earth, Vol. 4, 1961, pp. 99-185.

[28] P. Kassler, "The Structural and Geomorphic Evolution of the Persian Gulf," In: B. H. Purser, Ed., The Persian Gulf, Springer, New York, 1973, pp. 11-32. doi:10.1007/978-3-642-65545-6_2 
[29] J. H. Beard, J. B. Sangree and L. A. Smith, "Quaternary Chronology, Paleoclimate, Depositional Sequences and Eustatic Cycles," American Association of Petroleum Geologists Bulletin, Vol. 66, No. 2, 1982, pp. 158-169.

[30] P. Stoffer and D. A. Ross, "Late Pleistocene and Holocene Sedimentation in the Persian Gulf-Gulf of Oman," Sedimentary Geology, Vol. 23, No. 1-4, 1979, pp. 181208.

[31] T. A. Al-Asfour, "Changing Sea Level along the North
Coast of Kuwait Bay,” Kegan Paul International, London, 1982, $250 \mathrm{pp}$.

[32] T. Howard-Carter and R. H. Qaddumi, "Geology, Geography and Early Man in Kuwait," Handbook of the Arab Bureau of Education for the Gulf States, Riyadh, 1984.

[33] D. Ross, E. Uchupi and R. White, "The Geology of the Persian Gulf-Gulf Oman Region: A Synthesis," Review of Geophysics, Vol. 24, No. 3, 1986, pp. 537-556. 